Gut, 1988, 29, 642-646

\title{
Effects of fasting and refeeding on somatostatin concentration and binding to cytosol from rabbit gastric mucosa
}

\author{
B ROCA, R FERNANDEZ-VALENCIA, AND E ARILLA
}

From the Departamentos de Bioquímica y Biología Molecular y Ciencias Morfológicas, Facultad de Medicina, Universidad de Alcalá de Henares, Madrid, Spain

SUMMARY Somatostatin like immunoreactivity and the density of somatostatin binding sites were measured in stomach (fundus and antrum) from either fed, 12 to 96 hours fasted, or 96 hours fasted plus 48 hours refed rabbits. The somatostatin concentration increased in fundic and antral mucosa after $24 \mathrm{~h}$ and reached its highest value after $96 \mathrm{~h}$ of fasting. The number of specific somatostatin binding sites with high and low affinity decreased with the duration of fasting. Refeeding of fasted animals resulted in a normalisation to control values of gastric mucosal somatostatin and somatostatin binding.

Fasting increases the gastric somatostatin concentration in rats, ' a feature that may represent a significant regulatory mechanism in nutrient homeostasis. ${ }^{2}$ It is the somatostatin-binding site complex rather than somatostatin itself, however, that is required for a hormonal effect, and an increased concentration of gastric somatostatin does not necessarily imply more somatostatin binding site complexes. The number of such complexes is determined both by the concentration of somatostatin available for binding and the number and affinity of somatostatin binding sites. It has recently been shown in various tissues that the majority of cellular somatostatin-binding sites are located intracellularly, ${ }^{3.5}$ and there is evidence that the intracellular binding sites for somatostatin exist in a biologically active form. ${ }^{\circ}$ In this regard previously published studies have shown specific binding sites for somatostatin in cytosol isolated from gastric mucosa. ${ }^{57}$

In the present study we have investigated somatostatin binding to cytosol of gastric (fundic and antral) mucosa from rabbits subjected to short or long periods of starvation and from fasted refed rabbits. In addition, gastric somatostatin concentrations were studied in both conditions.

Address for correspondence: Dr E Arilla, Departamento de Bioquímica y Biología Molecular, Facultad de Medicina, Universidad de Alcalá de Henares. Madrid, Spain.

Received for publication 16 December 1987

\section{Methods}

ANIMALS AND CHEMICALS

All experiments were conducted with male rabbits (New Zealand) weighing $1 \cdot 5-2 \cdot 0 \mathrm{~kg}$. The animals were divided into three groups: group 1 was fed ad libitum $(n=25)$; group 2 was fasted $12(n=5), 24$ $(n=5), 48(n=5)$, or $96(n=5 h$; and group 3 was refed for $48 \mathrm{~h}$ after $96 \mathrm{~h}$ fasting $(\mathrm{n}=5)$.

The origin of the chemicals used was the same as in. ${ }^{~} \mathrm{Tyr}^{\prime \prime}$-somatostatin was radioiodinated by a chloramine-T method. ${ }^{9}$ The tracer was purified on a sephadex G-25 coarse column $(1 \times 100)$ which had been equilibrated with $0 \cdot 1 \mathrm{M}$ acetic acid containing bovine serum albumin $0 \cdot 1 \%(\mathrm{w} / \mathrm{v})$. The specific radioactivity of tracer was about $350 \mathrm{Ci} / \mathrm{g}$. The rabbit antibody used in the radio-immunoassay technique was purchased from the Radiochemical Centre (Amersham, UK). This antiserum was raised in rabbits against somatostatin-14 conjugated to bovine serum albumin and is specific for somatostatin but, as somatostatin-14 constitutes the $\mathrm{C}$-terminal portions of both somatostatin- 25 and somatostatin- 28 , the antiserum does not distinguish between these three forms.

TISSUE EXTRACTION AND RADIOIMMUNOASSAY OF SOMATOSTATIN

Animals were killed between 900 and 1000 am by 
cervical dislocation. The whole stomach was removed, opened along the greater curvature, and rinsed with cold saline. Antrum and fundus were separated. The mucosa (fundic and antral) was then dissected free from the underlying muscle layer and immediately boiled for five minutes in $1 \mathrm{~N}$ acetic acid (about $4 \mathrm{ml} / \mathrm{g}$ tissue) in order to destroy the proteolytic enzymes and coagulate the bulk of the proteins and homogenised briefly (one to two min) with a motordriven Teflon pestle. The homogenate was centrifuged at $3000 \mathrm{rpm}$ for $30 \mathrm{~min}$ at $4^{\circ} \mathrm{C}$ and the resultant supernatant was stored at $-70^{\circ} \mathrm{C}$ until assay. Just before assay, extracts were neutralised with $1 \mathrm{~N} \mathrm{NaOH}$. Somatostatin concentration was determined in tissue extracts by a radioimmunoassay method" using a rabbit antisomatostatin serum (final dilution usually 1:20000). Separation from antibody bound radioactivity was made by adding dextran coated charcoal (Norit A). The minimum detectable quantity of the assay was $40 \mathrm{pg} / \mathrm{g}$ mucosa. The intra assay and interassay coeficients of variation were $7.8 \%$ and $9.2 \%$ respectively. Dilution curve for rabbit tissue extracts were parallel to the standard curve.

\section{SUBCELLULAR FRACTIONATION}

Fundic and antral mucosa were incubated at $37^{\circ} \mathrm{C}$ for $30 \mathrm{~min}$ and then subsequently washed twice in order to remove endogenous somatostatin. Cytosol of gastric (fundic and antral) mucosa was isolated according to the method of Reyl-Desmars and Lewin. ${ }^{5}$ Protein was estimated by the method of Lowry et $a l^{\prime \prime}$ using bovine serum albumin as a standard.

\section{BINDING STUDIES}

These studies were carried out as previously described.' In standard conditions, cytosol of rabbit gastric mucosa $(0.2 \mathrm{mg}$ protein $/ \mathrm{ml})$ was incubated in $0.5 \mathrm{ml}$ of a medium $(\mathrm{pH} 7.4)$ of the following composition: $0.5 \mathrm{mM} \mathrm{NaH} \mathrm{PO}_{4}, 1 \mathrm{mM} \mathrm{Na}_{2} \mathrm{HPO}_{4}, 80$ $\mathrm{mM} \mathrm{NaCl}, 5 \mathrm{mM} \mathrm{KCl}, 1 \mathrm{mM} \mathrm{CaCl}_{2}, 1.5 \mathrm{mM} \mathrm{MgCl}_{2}$, $50 \mathrm{mM}$ HEPES (N-2-hydroxyethylpiperazine- $\mathrm{N}^{\prime}-2$ ethanesulphonic acid), $11 \mathrm{mM}$ glucose, $0 \cdot 1 \%$ bovine serum albumin, $0 \cdot 1 \mathrm{mg} / \mathrm{ml}$ trypsin inhibitor, and 50 pM ${ }^{125}{ }^{25}$-Tyr ${ }^{11}$-somatostatin either alone or together with increasing concentration of unlabelled somatostatin (up to $2 \mu \mathrm{M}$ ). Unless otherwise indicated, incubations were done at $25^{\circ} \mathrm{C}$ for $60 \mathrm{~min}$. ${ }^{125} \mathrm{I}-\mathrm{Tyr}^{11}-$ somatostatin associated with cytosolic proteins was determined after removal of unbound tracer by $0.25 \%$ activated charcoal, $0.5 \%$ bovine serum albumin and $0.025 \%$ T70 dextran. ${ }^{36}$ 'Specific' binding was estimated as the difference between 'total' binding - that is, in the presence of tracer alone, and 'non-specific' binding as measured in the presence of
$4 \mu \mathrm{M}$ unlabelled somatostatin. This non-specific component represented about $45 \%$ of the binding observed in the absence of unlabelled somatostatin. The integrity of bound ${ }^{125} \mathrm{I}-\mathrm{Tyyr}^{11}$-somatostatin was assessed by talc adsorption, as previously described. ${ }^{12}$

STATISTICAL ANALYSIS

The statistical evaluation was performed using linear regression analysis and the parametric one-way analysis of variance and significant differences between experimental groups were evaluated by Newman Keuls multiple comparison procedures. The criterion of statistical significance was $p<0 \cdot 05$. Each individual experiment was performed in triplicate. Data are expressed as means (SE).

\section{Results}

Gastric (fundic and antral) mucosal somatostatin concentration increased after $24 \mathrm{~h}$ and reached its highest level after $96 \mathrm{~h}$ of fasting (Table 1). Two days of refeeding after $96 \mathrm{~h}$ of fasting returned the concentration of fundic and antral mucosal somatostatin to control values (Table 1).

The specific binding of ${ }^{125} \mathrm{I}^{-\mathrm{Tyr}^{11}}$-somatostatin to cytosol from rabbit fundic and antral mucosa from both fed and fasted rabbits depended on time, becoming maximal by $60 \mathrm{~min}$ and then remaining stable until at least $120 \mathrm{~min}$ in agreement with previous studies. ${ }^{7}$ Therefore all subsequent studies were performed for $60 \mathrm{~min}$ at $25^{\circ} \mathrm{C}$. The inactivation of the peptide by cytosol was similar $(25-30 \%$ after $60 \mathrm{~min}$ incubation at $25^{\circ} \mathrm{C}$ ) in all cases. The dissociation of the complex labelled peptide-cytosol was studied by the addition of $4 \mu \mathrm{M}$ somatostatin to the incubation mixture at steady-state. The corresponding dissociation patterns for the cytosolic preparations of fed and fasted rabbits were practically identical and similar to those previously reported

Table 1 Somatostatin-like immunoreactivity (SLI) concentration in fundic and antral mucosa of fed, fasted (12, 24,48 , and $96 h$ ) and fasted-refed rabbits. Results are expressed in ng somatostatin/mg protein as the mean (SE)

\begin{tabular}{lccr}
\hline & Fundus & Antrum & $n$ \\
\hline Fed & $3 \cdot 9(0 \cdot 3)$ & $4 \cdot 5(0 \cdot 7)$ & 25 \\
12h fasting & $4 \cdot 2(0 \cdot 2)$ & $5 \cdot 0(0 \cdot 2)$ & 5 \\
24 h fasting & $5 \cdot 9(1 \cdot 4)^{*}$ & $8 \cdot 7(1 \cdot 1)^{*}$ & 5 \\
48h fasting & $6 \cdot 3(0 \cdot 7)^{\dagger}$ & $9 \cdot 2(1 \cdot 4)^{\dagger}$ & 5 \\
96h fasting & $11 \cdot 3(1 \cdot 5) \ddagger$ & $12 \cdot 2(1 \cdot 7)^{\ddagger}$ & 5 \\
96h fasting plus & $3 \cdot 3(0 \cdot 5)$ & $4 \cdot 8(0 \cdot 5)$ & 5 \\
$\quad$ & & & \\
\hline
\end{tabular}

Statistical comparisons versus fed controls: ${ }^{*} \mathrm{p}<0 \cdot 05,+\mathrm{p}<0 \cdot 01$, and $\neq \mathrm{p}<0 \cdot 001$. 


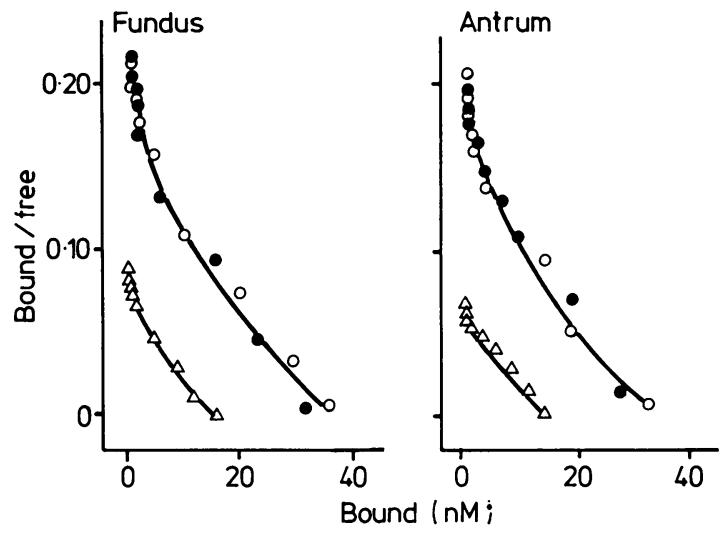

Figure Scatchardanalysis of the somatostatin binding data of fed $(\bigcirc), 96(\triangle) \mathrm{h}$ fasted and $96 \mathrm{~h}$ fasted plus $48 \mathrm{~h}$ refed $(\mathrm{O})$ rabbits. For the sake of clarity, intermediate periods are not represented, but the corresponding equilibrium binding parameters are included in the Table 2.

in. ' The time at with $50 \%$ of the ${ }^{125} \mathrm{I}-\mathrm{Tyr}^{\prime \prime}$ somatostatin dissociated from the cytosol varied between 16-20 $\mathrm{min}$ in the different groups considered.

The binding of ${ }^{125} \mathrm{I}-\mathrm{Tyr}^{11}$-somatostatin to cytosol of fasted rabbit gastric mucosa was significantly lower from 24 to $96 \mathrm{~h}$ but not after $12 \mathrm{~h}$ of fasting than that in fed rabbits both in the absence or in the presence of somatostatin concentrations ranging from $1 \mathrm{mM}$ to $2 \mu \mathrm{M}$. Because the observed differences in somato- statin binding could be caused by changes in either affinity or capacity of somatostatin binding sites, the stoichiometric data were interpreted by the method of Scatchard. ${ }^{13}$ The corresponding Scatchard plots exhibited curvilinear, concave upward curves that were analysed on the basis of two classes of somatostatin binding sites (Figure). A least square regression line was drawn to fit the low affinity site using the four higher somatostatin concentrations. The contribution of this site was subtracted from the binding obtained at the lower somatostatin concentrations to obtain the high-affinity binding. Table 2 shows the corresponding equilibrium parameters for the high affinity-low capacity and for the low affinity-high capacity sites. The observed differences must be accounted for by a decrease of the number of both classes of somatostatin binding sites in rabbits fasted for 24-96 $\mathrm{h}$ rather than changes in their affinity. Finally, $48 \mathrm{~h}$ of refeeding after $96 \mathrm{~h}$ of fasted resulted in binding values similar to those in the fed condition.

A significant negative correlation $(r=-0.544$, $p<0.05$ ) was found between the somatostatin concentration and the density of somatostatin binding sites.

\section{Discussion}

Our data provide evidence that gastric (fundic and antral) mucosa somatostatin concentrations increased in fasted rabbits after $24 \mathrm{~h}$, whereas the number of somatostatin binding sites of high and low

Table 2 Effect of fasting refeeding on equilibrium parameters of somatostatin binding to cytosol of gastric mucosa. Values were obtained by Scatchard ${ }^{13}$ analysis of data of Fig. 1 .

\begin{tabular}{|c|c|c|c|c|c|}
\hline & \multicolumn{2}{|l|}{ Fundus } & \multicolumn{2}{|l|}{ Antrum } & \multirow[b]{2}{*}{$n$} \\
\hline & High affinity binding sites & Low affinity binding sites & High affinity binding sites & Low affinity binding sites & \\
\hline Fed & & & & & 25 \\
\hline $\mathrm{Kd}$ & $17 \cdot 9(4 \cdot 5)$ & $225(17)$ & $22 \cdot 7(3 \cdot 8)$ & $206(22)$ & \\
\hline$B \max$ & $2 \cdot 5(0 \cdot 3)$ & $197(14)$ & $2 \cdot 7(0 \cdot 2)$ & $170(15)$ & \\
\hline $12 \mathrm{~h}$ fasting & & & & & 5 \\
\hline $\mathrm{Kd}$ & $16 \cdot 8(2 \cdot 5)$ & $205(22)$ & $24 \cdot 4(2 \cdot 7)$ & $186(24)$ & \\
\hline Bmax & $2 \cdot 2(0 \cdot 5)$ & $175(23)$ & $2 \cdot 3(0 \cdot 2)$ & $160(12)$ & \\
\hline $24 \mathrm{~h}$ fasting & & & & & 5 \\
\hline $\mathrm{Kd}$ & $19 \cdot 2(3 \cdot 2)$ & $218(28)$ & $21 \cdot 3(2 \cdot 9)$ & $210(23)$ & \\
\hline Bmax & $1 \cdot 2(0 \cdot 1)^{*}$ & $133(11)^{*}$ & $1.8(0 \cdot 1)^{*}$ & $139(14)$ & \\
\hline $48 \mathrm{~h}$ fasting & & & & & 5 \\
\hline $\mathrm{Kd}$ & $18 \cdot 2(4 \cdot 3)$ & $191(27)$ & $20 \cdot 2(5 \cdot 5)$ & $200(20)$ & \\
\hline Bmax & $0 \cdot 7(0 \cdot 1)^{*}$ & $107(12)^{*}$ & $0 \cdot 7(0 \cdot 1)^{*}$ & $122(16)^{*}$ & \\
\hline $96 \mathrm{~h}$ fasting & & & & & 5 \\
\hline $\mathrm{Kd}$ & $18 \cdot 7(2 \cdot 8)$ & $220(47)$ & $22 \cdot 6(3 \cdot 8)$ & $192(22)$ & \\
\hline $\mathrm{Bmax}$ & $0 \cdot 6(0 \cdot 1)^{*}$ & $96(10)^{*}$ & $0.5(0 \cdot 2)^{*}$ & $72(17)^{*}$ & \\
\hline $96 \mathrm{~h}$ fasting plus $48 \mathrm{~h}$ refeeding & & & & & 5 \\
\hline $\mathrm{Kd}$ & $20 \cdot 1(3 \cdot 6)$ & $249(20)$ & $23 \cdot 2(4 \cdot 3)$ & $203(20)$ & \\
\hline Bmax & $3 \cdot 0(0 \cdot 3)$ & $195(12)$ & $2 \cdot 9(0 \cdot 1)$ & $165(12)$ & \\
\hline
\end{tabular}

$\mathrm{Kd}$ is the equilibrium dissociation constant, $\mathrm{nM}$. Bmax is the binding capacity pmol somatostatin/mg protein. Mean values (SE). ${ }^{*} \mathrm{p}<0 \cdot 05$ or less $v$ fed controls. 
affinity decreased (without changes in the affinity values) in the cytosol from gastric mucosa, as compared to control conditions. Refeeding of fasted ahimals resulted in a normalisation to control values of gastric mucosal somatostatin and somatostatin binding.

The physiopathological significance of a decrease in somatostatin binding sites in gastric mucosa after fasting remains to be elucidated. Other studies, however, have shown that somatostatin exerts cytoprotective activity on gastric mucosa ${ }^{1+15}$ and that longterm food reduction in rabbits damages the gastric mucosa producing ulceration and macroscopical haemorrhage. ${ }^{16}$ These previous findings together with present results support the hypothesis that the decrease in the number of gastric mucosal somatostatin binding sites may imply decreased sensitivity of the gastric mucosa to endogenous somatostatin and could thus contribute to the pathogenesis of gastric ulcer in longterm fasting.

When studying different durations of starvation, there is some controversy in the literature on whether antral somatostatin concentrations increases ${ }^{17}$ or remains constant. ${ }^{218}$ Investigations on the fundic somatostatin content give additional evidence that they decrease ${ }^{19}$ or are constant. ${ }^{17}$ The discrepances may be explained in terms of differences in the preparations used - that is, whole gastric wall $v$ isolated mucosa, besides species differences. On the other hand, it has been shown that antral D-cell density decreases in longterm fasted rats whereas fundic D-cell density remains constant. ${ }^{20}$ The discrepancy between changes in mucosal somatostatin concentration and D-cell number in gastric mucosa still awaits an explanation. In addition, investigations on the influence of food deprivation on the release of gastric somatostatin like immunoreactivity (SLI) have shown that somatostatin responses were the same after prolonged starvation compared with fed or short term fasted rats in vitro using the isolated, vascularly perfused rat stomach. ${ }^{19}$ As the fundus is the predominant source of somatostatin secretion in this model, this suggests that the unchanged density of fundic D-cells during fasting reflects the functional activity of the D-cell much better than the mucosal somatostatin concentration; whether the increase in gastric SLI reflects increased biosynthesis, decreased release from the D-cell, or diminished degradation cannot be answered at this time.

The binding of somatostatin was significantly higher in the gastric (fundic and antral) mucosa from fed than fasted rabbits. Interestingly, gastrin binding to gastric mucosa also decreases after fasting. ${ }^{21}$

Present affinity values are not compatible with the low circulating levels of the peptide, however, the presence of somatostatin in paracrine cells ${ }^{22}$ at the gastric mucosa should be kept in mind. This paracrine localisation is consistent with local concentrations of somatostatin high enough to interact with the reported binding sites.

The mechanism by which the alteration of the number of somatostatin binding sites occurs is unknown. Although hormone induced depletion of binding sites has been found to be dependent on ${ }^{2324}$ and independent of ${ }^{256}$ protein synthesis, however, it seems that new protein synthesis is required for the return to a normal density of peptide binding sites. ${ }^{26}$

Because fasting decreases the protein synthesis, ${ }^{27}$ the decreased binding capacity in this condition may reflect a decrease in the synthesis of new binding sites. Refeeding of fasted animals stimulates protein synthesis ${ }^{27}$ and the number of somatostatin binding sites returns to fed values.

Interaction between somatostatin and other hormones may also result in a decrease of the number of binding sites. As starvation increases the plasma concentration of cortisol, ${ }^{2 \times}$ and these hormone levels are known to decrease the concentration of somatostatin binding sites, ${ }^{2 y}$ the possibility exists that these altered hormone levels may affect somatostatin binding sites in cytosol from rabbit antral and fundic gastric mucosa.

The authors are greatly indebted to Professor J C Prieto for useful criticism and help in preparing the manuscript, and to Professor L Gomez Pellico for his encouragement and support throughout this study. This work was supported by a grant from the Fondo de Investigaciones de la Seguridad Social (86/911).

\section{References}

1 Voyles NR, Awoke S, Wade A, Bhatena SJ, Smith SS, Recant L. Starvation increases gastrointestinal somatostatin in normal and obese zucker rats: a possible regulatory mechanism. Horm Metabol Res 1982; 14: 392-5.

2 Tannenbaum GS, Rorstad O, Brazeau P. Effects of prolonged food deprivation on the ultradian growth hormone rhythm and immunoreactive somatostatin tissue levels in the rat. Endocrinology 1979; 104: 1733-8.

3 Ogawa N, Thompson T, Friesen HG. Properties of soluble somatostatin-binding protein. Biochem J 1977; 165: 269-77.

4 Draznin B, Mehler P, Steinberg J, Leither JW, Sussman $\mathrm{KE}$. Intracellular migration of somatostatin receptors during exocytosis [Abstract]. J Cell Biol 1983; 97: 410A.

5 Reyl-Desmars J, Lewin MJM. Evidence for an intracellular somatostatin receptor in pancreas: a compara- 
tive study with reference to gastric mucosa. Biochem Biophys Res Commun 1982; 109: 1324-31.

6 Reyl FJ, Lewin MJM. Intracellular receptor for somatostatin in gastric mucosal cells: Decomposition and reconstitution of somatostatin-stimulated phosphoprotein phosphatases. Proc Natl Acad Sci USA 1982; 79: 978-82.

7 Guijarro LG, Arilla E, López-Ruiz MP, Prieto JC, Whitford C, Hirst BH. Somatostatin binding sites in cytosolic fraction isolated from rabbit antral and fundic gastric mucosa. Regul Peptides 1985; 10: 207-15.

8 Arilla E, López-Ruiz MP, Gonzalez-Guijarro L, Prieto JC, Gómez-Pan A, Hirst BH. Characterization of somatostatin binding sites in cytosolic fraction of rat intestinal mucosa. Biochim Biophys Acta 1984; 802: 203-8.

9 Greenwod FC, Hunter WM, Glover JS. The preparation of ${ }^{131}$ I-labelled human growth hormone of high specific radioactivity. Biochem J 1963; 89: 114-23.

10 Gerich J, Greene K, Hara M, Rizza R, Patton G. Radioimmunoassay of somatostatin and its application in the study of pancreatic somatostatin secretion in vitro. J Lab Clin Med 1979; 93: 1009-17.

11 Lowry OH, Rosebrough NY, Farr AL, Randall RJ. Protein measurement with the Folin phenol reagent. J Biol Chem 1951; 193: 265-75.

12 Conlon JM, Whittaker J, Hammond V, Alberti KGMM. Metabolism of somatostatin and its analogues by the liver. Biochim Biophys Acta 1981; 677: 234-42.

13 Scatchard G. The attraction of protein for small molecules and ions. Ann NY Acad Sci 1949; 51: 660-72.

14 Szabo S, Usadel KH. Cytoprotection-organo protection by somatostatin: gastric and hepatic lesions. Experientia 1982; 38: 254-6.

15 Usadel KH, Wdowinski JM, Schwedes U. New aspects of the general mode of action of somatostatin. In: Angelini L, Usadel KH, eds. Therapeutic Effects of Somatostatin. Rome, Italy: Serono Symposia, 1984: 37-46.

16 Nissim JA. Gastrointestinal lesions in starvation induced by drugs or simple food reduction. Lancet 1961 ; i: $132-5$.

17 Shulkes A, Caussignac Y, Lamers CB, Solomon TE, Yamada T, Walsh JH. Starvation in the rat effect on peptides of the gut and brain. Aust J Exp Biol Med Sci 1983; 61: 581-7.

18 Tanigawa $\mathrm{K}$, Kuzuya $\mathrm{H}$, Seino $\mathrm{Y}$, et al. Effect of starvation on somatostatin content of pancreas and gastrointestinal tract of the guinea pig. Horm Metab Res 1982; 14: 245-7.

19 Koop H, Schwab E, Arnold R, Creutzfeldt W. Effect of food deprivation on rat gastric somatostatin and gastrin release. Gastroenterology 1982; 82: 871-6.

20 Schwarting H, Koop H, Gellert G, Arnold R. Effect of starvation on endocrine cells in the rat stomach. Regul Peptides 1986; 14: 33-9.

21 Speir GR, Takeuchi K, Peitsch W, Johnson LR. Mucosal gastrin receptor II. Up- and down-regulation. Am J Physiol 1982; 242G: 243-9.

22 Alumets J, Ekelund M, El Munshid HA, Håkanson R, Loren I, Sundler F. Topography of somatostatin cells in the stomach of the rat: Possible functional significance. Cell Tissue Res 1979; 202: 177-88.

23 De Meyts P, Kahn CR, Roth J, Bar RS. Hormonal regulation of the affinity and concentration of hormone receptors in target cells. Metabolism 1976; 25: 1365-70.

24 Hinkle PM, Tashjian AH. Thyrotrophin-releasing hormone regulates the number of its own receptors in the $\mathrm{GH}_{3}$ strain of pituitary cells in culture. Biochemistry 1976; 14: 3845-51.

25 Mukherjee C, Caron MG, Lefkowitz RJ. Catecholamine-induced subsensitivity of adenylate cyclase associated with loss of B-adrenergic receptor binding sites. Proc Natl Acad Sci USA 1975; 72: 1945-9.

26 Lesniak MA, Roth JJ. Regulation of receptor concentration by homologous hormone. J Biol Chem 1976; 251: 3720-9.

27 Majumdar APN. Regulation of gastric mucosal DNA synthesis during fasting and refeeding in rats. Digestion 1983; $27: 36-43$.

28 Palmblad J, Levi L, Burger A, et al. Effects of total energy withdrawal (fasting) on the levels of growth hormone, thyrotropin, cortisol, adrenaline, noradrenaline, $\mathrm{T}_{4}, \mathrm{~T}_{3}$ and $\mathrm{rT}_{3}$ in healthy males. Acta Med Scand 1977; 201: 15-22.

29 Schonbrum A. Glucocorticoids down-regulate somatostatin receptors in pituitary cells in culture. Endocrinology 1982; 110 : 1147-54. 